\title{
Particle flux in the Rainbow hydrothermal vent field (Mid-Atlantic Ridge): Dynamics, mineral and biological composition
}

\author{
by Alexis Khripounoff ${ }^{1}$, Annick Vangriesheim ${ }^{1}$, Philippe Crassous ${ }^{1}$, \\ Michel Segonzac $^{1}$, Ana Colaço ${ }^{2}$, Daniel Desbruyères ${ }^{1}$ and Roxane Barthelemy $^{3}$
}

\begin{abstract}
In order to provide information about the export and the distribution of hydrothermal particulate material to the surrounding deep ocean, four moorings were deployed in the vicinity of the hydrothermal Rainbow vent field (Mid-Atlantic Ridge, $36^{\circ} 14^{\prime} \mathrm{N}, 2250 \mathrm{~m}$ depth). The first mooring was a sediment trap with a current meter deployed at $2 \mathrm{~m}$ from a chimney of the Rainbow vent field and $1.5 \mathrm{~m}$ above the bottom (a.b.) for 16 days. It represented the reference for the initial composition of particles produced by the vent. The total mean mass particle flux $\left(6.9 \mathrm{~g} \mathrm{~m}^{-2} \mathrm{~d}^{-1}\right)$ was distinctly higher than the flux measured at the shallower hydrothermal vents on the MAR segment. This particulate flux showed a high temporal variation at the scale of a few days and was characterizedby a high concentration of sulphur (17.2\%) and copper (3.5\%) and a very low concentration of organic carbon $(0.14 \%)$. Several hundred bivalve larvae belonging to the hydrothermal mytilid Bathymodiolus azoricus were collected in this trap at the beginning of the experiment. The density of larvae decreased strongly at the end, indicating a patchiness distribution or a discontinuous reproduction of this species. The other three moorings, including sediment traps, current-meters and thermistor chains, were deployed for 304 days at different distances and altitudes from the Rainbow vent field. The mean speed of the current in the rift valley was low $\left(6 \mathrm{~cm} \mathrm{~s}^{-1}\right)$ and was oriented toward the north. The total mean particle mass flux measured with the five sediment traps varied little, from 10.6 to $25.0 \mathrm{mg} \mathrm{m} \mathrm{m}^{-2} \mathrm{~d}^{-1}$, and displayed temporal variations which are typical of deep-sea environments with seasonal changes in the overlying production. However, in the trap at $500 \mathrm{~m}$ from the vents $150 \mathrm{~m}$ a.b., the presence of the hydrothermal plume can be observed: the sulphur, iron and copper concentrations of particles were significantly higher compared to the particles sampled in the pelagic reference trap. The plume composition was about 50\% hydrothermal particles and $50 \%$ pelagic particles and its upper limit reached $300 \mathrm{~m}$ a.b. at this distance. In the traps at $1000 \mathrm{~m}$ from the vents, the elemental composition of particles was similar to the pelagic particles and we assume that these traps were not in the plume during the experiment. The zooplankton obtained in the long-term trap samples revealed high density variations in relation to the distance from the vent site. The nutrient enrichment around the hydrothermal area and the abundance of free living bacteria explain these variations in zooplankton density.
\end{abstract}

1. IFREMER Centre de Brest, Département DRO/EP, BP 70, 29280 Plouzané, France. email: alexis.khripounoff@ifremer.fr

2. IMAR, Laboratório Maritimo da Guia, Faculdade da Ciencias de Lisboa, Estrada do Guincho, 2750 Cascais, Portugal.

3. Université de Provence, Laboratoire de Biologie Animale, 3 place Victor Hugo, 13331 Marseille Cedex 3, France. 


\section{Introduction}

The most spectacular manifestations of hydrothermal activity are the high-temperature vent fields, which create particle-rich plumes rising hundreds of meters above the sea floor. The production of this particulate material and its dispersal to the deep ocean mostly depends on the emission of vent fluids that are precipitated as fine particles carried by the neutrally buoyant hydrothermal plume. The hydrothermal plumes, transported by the deep currents, can be detected up to $100 \mathrm{~km}$ from the emitting vent (Dymond and Roth, 1988; German and Sparks, 1993). The study of plumes is now an important part of hydrothermal research because of the influence of vent fluids on the ocean chemical balance (see Elderfield and Schultz, 1996). Hydrothermal activity also supports the production of biomass such as planktonic larval stages or juveniles of vent species. These are carried by the near-bottom currents and/or the buoyant hydrothermal plume and are then transported several hundred meters above the bottom (Herring and Dixon, 1998; Kim et al., 1994; Kim and Mullineaux, 1998; Mullineaux and France, 1995; Mullineaux et al., 1995). Through these processes, hydrothermal plumes participate in the dispersal of vent species along the mid-ocean ridges and constitute a possible food source for the surrounding deep-sea fauna.

The aim of this work is to assess the influence of the hydrothermal plume in the surrounding ocean. The Rainbow hydrothermal field $\left(36^{\circ} 15^{\prime} \mathrm{N}\right)$ was chosen because it produces the strongest plume of its kind known on the Mid-Atlantic Ridge (German et al., 1996; Fouquet et al., 1997), making it an ideal natural laboratory to study plume processes. To provide information about production and export of hydrothermal material by vents and plumes to the deep ocean, four moorings with sediment traps, current meters and thermistor chains were deployed at different distances from the Rainbow site for periods varying from 16 days to 10 months.

\section{Materials and methods}

a. Study area (Fig. 1a)

The Rainbow site $\left(36^{\circ} 14^{\prime} \mathrm{N}, 33^{\circ} 54^{\prime} \mathrm{W}, 2250 \mathrm{~m}\right.$ depth) was detected on the Azores Mid-Atlantic Ridge segment (AMAR) in 1996 (German et al., 1996) and observed by submersible in 1997 (Fouquet et al., 1997, 2001; German et al., 2001). It is situated on the flank of a raised block of ultramafic basement in the discontinuity between two segments of the ridge and produces a strong and persistent hydrothermal plume. It is one of the most active hydrothermal vent fields discovered in the North Atlantic with at least ten major groups of extremely active black smokers without visible fauna. Some diffusive vents are present, located 25-100 m from black smokers with small mussel beds and shrimp swarms (Desbruyères et al., 2001).

\section{b. Sampling}

i. Mooring S (Short-term mooring with small sediment traps). On the Rainbow hydrothermal vent field (Fig. 1a), one triplicate sediment trap frame (trap S) was deployed 

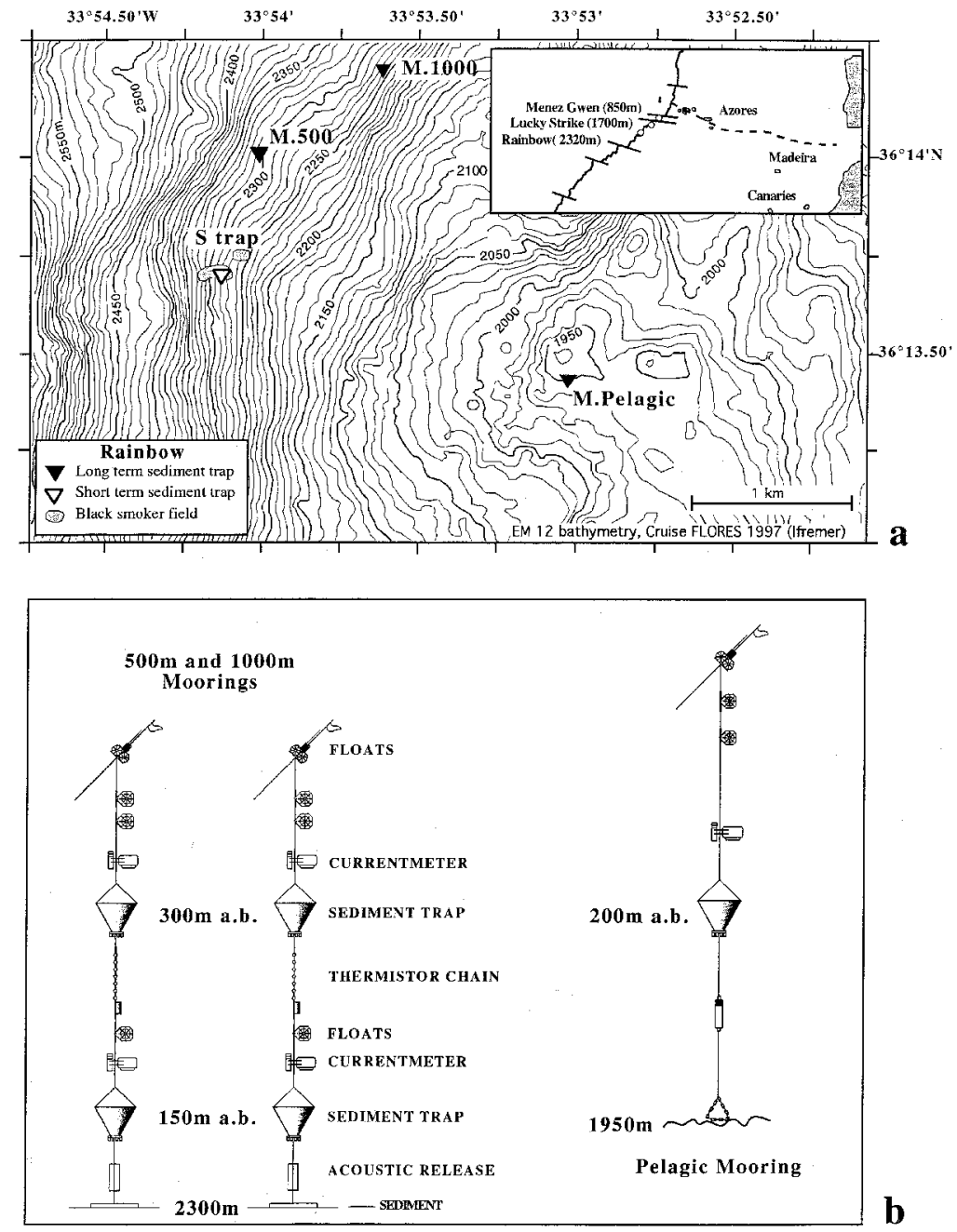

Figure 1. (a) Bathymetric map showing the location of the Rainbow field with the positions of the different moorings. (b) Scheme of the long-term moorings.

$\left(36^{\circ} 13.8 \mathrm{~N}, 33^{\circ} 54.1 \mathrm{~W}\right)$ during the Marvel cruise (August 1997) by the submersible Nautile for 16 days at $2 \mathrm{~m}$ in the southwest of an active vent field ( $2275 \mathrm{~m}$ depth). The description of the deployment method is detailed in Khripounoff and Alberic (1991). The topcollecting surface of traps was situated $1.5 \mathrm{~m}$ above the bottom (a.b.), while an Aanderaa current-meter with a recording interval of 5 minutes was positioned $2 \mathrm{~m}$ above the trap. The settling particles were collected in 3 epoxy fibreglass traps of cylindrical-conic shape with 5 collection bottles each and assembled ( $\mathrm{S}$ trap) on a single frame (Khripounoff and Alberic, 1991). Only 4 collectors were used with a sampling period of 4 days each. Each sediment trap had a sampling aperture of $0.07 \mathrm{~m}^{2}$ and was covered with a honeycomb 
baffle of $1 \mathrm{~cm}$ diameter and $10 \mathrm{~cm}$ deep cells at the top. Prior to deployment, the sampling bottles of two traps were filled with filtered seawater containing sodium borate buffered formalin to give a final concentration of $3 \%$ in order to prevent in situ microbial decomposition. The bottles of the third trap were filled with a buffer composed of $5 \mathrm{M}$ $\mathrm{NaCl}, 10 \%$ DMSO and $0.001 \%$ bromophenol blue to prevent in situ DNA degradation (Comtet et al., 2000). After recovery, the samples were stored in the dark at $4{ }^{\circ} \mathrm{C}$ pending analyses.

ii. Moorings L (Long-term moorings with large traps). Three moorings (Fig. 1b) with sediment traps, current meters and thermistor chains were deployed on the Rainbow field during the Marvel cruise (August 1997) and recovered during the Flame 2 cruise (June 1998). The settling particles were collected over 304 days using cone-shaped traps (PPS5 model, Technicap ) with 22 collection bottles. These traps had a sampling aperture of $1 \mathrm{~m}^{2}$ and were covered with a honeycomb baffle of $1 \mathrm{~cm}$ diameter and $10 \mathrm{~cm}$ deep cells at the top. As in the S mooring, the sampling bottles were filled with filtered seawater and sodium borate buffered formalin to give a final concentration of $3 \%$. The sampling periods were 14 days each except for the last collector (10 days).

The aim of the first mooring (H500) was to sample the rising hydrothermal plume. Its position was selected according to the CTD results obtained in this area by German et al. (1998). It was deployed $\sim 500 \mathrm{~m}$ to the north of the Rainbow vents at $2300 \mathrm{~m}$ depth (M500) with two traps (150 $\mathrm{m}$ and $300 \mathrm{~m}$ a.b.), two current-meters and a thermistor chain in between. Unfortunately, the trap at $150 \mathrm{~m}$ a.b. did not work properly between February and April ( 7 collectors). The location $\left(34^{\circ} 14.0 \mathrm{~N}, 33^{\circ} 54.0 \mathrm{~W}\right)$ and depth are those obtained on the vessel at the mooring launching (Fig. 1). Due to a possible drift during the mooring descent, its exact location on the bottom and its depth are given at $\pm 100 \mathrm{~m}$. The second mooring (M1000), with the same configuration as the first, was used to study the neutrally buoyant hydrothermal plume. It was deployed $\sim 1000 \mathrm{~m}\left(36^{\circ} 14.2 \mathrm{~N}, 33^{\circ} 53.6 \mathrm{~W}\right)$ to the north-northeast of the vents at $2250 \mathrm{~m}$ depth. The last mooring (M Pelagic), with only one trap at $200 \mathrm{~m}$ a.b. and one current-meter, was positioned $\left(36^{\circ} 13.3 \mathrm{~N}, 33^{\circ} 52.8 \mathrm{~W}\right)$ at $1950 \mathrm{~m}$ depth, away from the axis at $\sim 2 \mathrm{~km}$ to the southeast of the vents. It was intended to sample the pelagic flux only as a reference (Fig. 1). On each of the three moorings, an Aanderaa current-meter was installed $10 \mathrm{~m}$ above each trap. The current-meters were equipped with a narrow range temperature sensor (resolution: $0.006^{\circ} \mathrm{C}$ ) and a pressure sensor. The current and its direction as well as temperature and pressure were recorded every hour. For the moorings M500 and M1000, thermistor chains, consisting of ten thermistors (narrow range), $10 \mathrm{~m}$ apart, were fixed between the two traps, i.e. between $210 \mathrm{~m}$ and $310 \mathrm{~m}$ above the bottom. All the current, temperature and pressure sensors were calibrated before and after the experiment.

\section{c. Current data}

Time-series analysis of current data has been performed following methods as described in Emery and Thomson (1998). To examine the fluctuations of the residual current and 
Table 1. Current data obtained with current-meters fixed on the short (Mooring S) and the long-term moorings (M Pelagic, M500 and M1000).

$\begin{array}{lcclccc}\text { Moorings } & \begin{array}{c}\text { Duration } \\ \text { (days) }\end{array} & \begin{array}{c}\text { Altitude } \\ \text { (a.b.) }\end{array} & \begin{array}{c}\text { Residual } \\ \text { current } \\ \text { direction }\end{array} & \text { Mean speed } & \text { Max. speed } & \begin{array}{c}\text { Residual } \\ \text { current } \\ \text { speed }\end{array} \\ \text { Mooring S } & 16 & 1.5 \mathrm{~m} & \mathrm{~N} 330^{\circ} & 9 \mathrm{~cm} \mathrm{~s}^{-1} & 19 \mathrm{~cm} \mathrm{~s}^{-1} & 2.9 \mathrm{~cm} \mathrm{~s}^{-1} \\ \text { M Pelagic } & 304 & 210 \mathrm{~m} & \mathrm{~N} 310^{\circ} & 5 \mathrm{~cm} \mathrm{~s}^{-1} & 14 \mathrm{~cm} \mathrm{~s}^{-1} & 1.1 \mathrm{~cm} \mathrm{~s}^{-1} \\ \text { M500 } & 304 & 310 \mathrm{~m} & \text { N005 } & 6 \mathrm{~cm} \mathrm{~s}^{-1} & 17 \mathrm{~cm} \mathrm{~s}^{-1} & 3.1 \mathrm{~cm} \mathrm{~s}^{-1} \\ \text { M500 } & 304 & 160 \mathrm{~m} & \text { N020 } & 6 \mathrm{~cm} \mathrm{~s}^{-1} & 18 \mathrm{~cm} \mathrm{~s}^{-1} & 4.5 \mathrm{~cm} \mathrm{~s}^{-1} \\ \text { M1000 } & 304 & 310 \mathrm{~m} & \mathrm{~N} 355^{\circ} & 6 \mathrm{~cm} \mathrm{~s}^{-1} & 17 \mathrm{~cm} \mathrm{~s}^{-1} & 1.5 \mathrm{~cm} \mathrm{~s}^{-1} \\ \text { M1000 } & 304 & 160 \mathrm{~m} & \mathrm{~N} 355^{\circ} & 6 \mathrm{~cm} \mathrm{~s}^{-1} & 18 \mathrm{~cm} \mathrm{~s}^{-1} & 3.4 \mathrm{~cm} \mathrm{~s}^{-1}\end{array}$

temperature, the instantaneous current data were low-pass filtered (Lanczos filter, cut-off period of 48 hours) to remove the tidal and inertial oscillations. The calculation of the eastward and northward current components (current vector components on the eastward and northward directions taken as $x$ and $y$ axis) and statistics (current, temperature, pressure) were made from the filtered and unfiltered data.

\section{d. Faunal sorting and particle analysis}

In the laboratory, each sample from the traps was sieved and the fraction $>250 \mu \mathrm{m}$ was examined under a dissecting microscope to sort and to count the organisms (particles smaller than $250 \mu \mathrm{m}$ contained negligible proportion of nauplii and juvenile copepods). The shell hinge structure was examined using a Philips XL30 Scanning Electron Microscope to identify bivalve larvae (Comtet et al., 2000). Then, the remaining particles were rinsed with Milli-Q purified water $(\mathrm{pH} \sim 7)$, freeze-dried and weighed. Total sulphur and carbon were determined in duplicate with a Leco CS-125 auto-analyzer. Organic carbon concentration was measured with a Leco WR12 elemental analyzer after removing carbonates with a $2 \mathrm{~N} \mathrm{HCl}$ solution (Weliky et al., 1983). Inorganic carbon content was calculated as the difference between total and organic carbon. Analysis of the chemical composition of particles was undertaken by EDAX 1 DX-4i X-ray spectrometry. Standards were prepared in the laboratory from pure chemical compounds. Particles and standards were strongly compressed ( 5 tons) to obtain a pellet of $3 \mathrm{~mm}$ in diameter with a very flat surface. The averaged accuracy of the analysis was $15 \%$ for the elements with a concentration $>1 \%$. Carbon and nitrogen stable isotope analyses were performed using a dual inlet Isotope Ratio Mass Spectrometer (Finnigan Mat Delta E) coupled with a Carlo Erba NA 1500 auto-analyzer following the method described in Marguillier et al. (1997).

\section{Results}

a. Currents and temperatures

Close to the vent, maximum current speed was $19 \mathrm{~cm} \mathrm{~s}^{-1}$, and the mean speed was $9 \mathrm{~cm} \mathrm{~s}^{-1}$ during the 16 days of experiment (Table 1). Currents had strong semi-diurnal oscillations (oriented to $\mathrm{N} 040^{\circ}-\mathrm{N} 220^{\circ}$ ) which were responsible for most of the speed and 
direction variability (Fig. 2a). A residual current of $2.9 \mathrm{~cm} \mathrm{~s}^{-1}$ was superimposed on the short-term fluctuations. During the 16 days of the experiment, its direction was almost steadily toward N330, perpendicular to the semi-diurnal current (Fig. 2a). The temperature fluctuated between $3.6^{\circ} \mathrm{C}$ and $10.1^{\circ} \mathrm{C}$. The highest temperatures were observed when the current direction was between $\mathrm{N} 070^{\circ}$ and $\mathrm{N} 295^{\circ}$ (Fig. 3) corresponding to the periods when the trap was under the vent effect. The temperature anomalies $\geq 4^{\circ} \mathrm{C}$ recorded by the current-meter were observed $11 \%$ of the time.

Currents were also dominated by the semi-diurnal oscillations oriented to N045 $-\mathrm{N} 225^{\circ}$ at M500 and M1000 (160 m and $310 \mathrm{~m}$ a.b.) and N070 $-\mathrm{N} 250^{\circ}$ at M Pelagic (210 m a.b.) (current data are summarized in Table 1). At the mooring situated $2 \mathrm{~km}$ from the vent (M Pelagic), the current was low (mean speed was $5 \mathrm{~cm} \mathrm{~s}^{-1}$ and maximum speed was $14 \mathrm{~cm} \mathrm{~s}^{-1}$ ) and the direction was more variable which led to a much lower residual current $\left(1.1 \mathrm{~cm} \mathrm{~s}^{-1}\right)$ toward the northwest (Fig. 4). This result indicates that this mooring, chosen as a pelagic reference, was out of the influence of the hydrothermal vents during the experiment.

At the moorings situated $500 \mathrm{~m}$ (M500) and $1000 \mathrm{~m}$ (M1000) from the Rainbow vents, the mean current speed was around $6 \mathrm{~cm} \mathrm{~s}^{-1}$ while the maximum speed reached $18 \mathrm{~cm} \mathrm{~s}^{-1}$ (Table 1). The currents measured at both moorings were similar at the two levels $(310 \mathrm{~m}$ a.b. and $160 \mathrm{~m}$ a.b.). The residual current (Fig. 4) was steadily toward the north at the upper level and veered slightly to the east at the deepest levels (parallel to the local bathymetry). The residual current was higher at the deepest levels and at the mooring nearest to the vent (4.5 and $3.4 \mathrm{~cm} \mathrm{~s}^{-1}$ at $160 \mathrm{~m}$ a.b. and 3.1 and $1.5 \mathrm{~cm} \mathrm{~s}^{-1}$ at $310 \mathrm{~m}$ a.b., at M500 and M1000, respectively). The steady direction was favorable for advection of the vent emissions toward the traps of these two moorings.

During this experiment, no temperature anomaly exceeding the background of the natural temperature variations was recorded. No variation could be connected to vent input. All the temperature records exhibited semi-diurnal oscillations. These oscillations were always higher at $310 \mathrm{~m}$ a.b. than at $160 \mathrm{~m}$ a.b. (maximum amplitudes: $0.5^{\circ} \mathrm{C}$ and $0.3^{\circ} \mathrm{C}$, respectively). The temperature minimum values appeared when the current was oriented northward; i.e., when the current went from the vent to the moorings. This observation suggests that the temperature oscillations were only due to the background internal tides and not to the vent influence.

\section{b. Total mass particle fluxes}

Near the Rainbow vents (trap S), mean particle flux was $6.9 \mathrm{~g} \mathrm{~m}^{-2} \mathrm{~d}^{-1}$ (range 0.28 $19.2 \mathrm{~g} \mathrm{~m}^{-2} \mathrm{~d}^{-1}$ ). Figure 5a shows the high temporal variations of the mass fluxes during the 16 days of the experiment. During the first and third sampling periods, the particle fluxes were similar. The flux was maximum in sample 2 and was 50 times higher than the last sampling (sample 4).

Over the 304 days, the mean particle flux measured with the sediment trap far from the hydrothermal influence (M Pelagic) was $11.2 \mathrm{mg} \mathrm{m}^{-2} \mathrm{~d}^{-1}$ (range $0.45-61.7 \mathrm{mg} \mathrm{m}^{-2} \mathrm{~d}^{-1}$ ). 

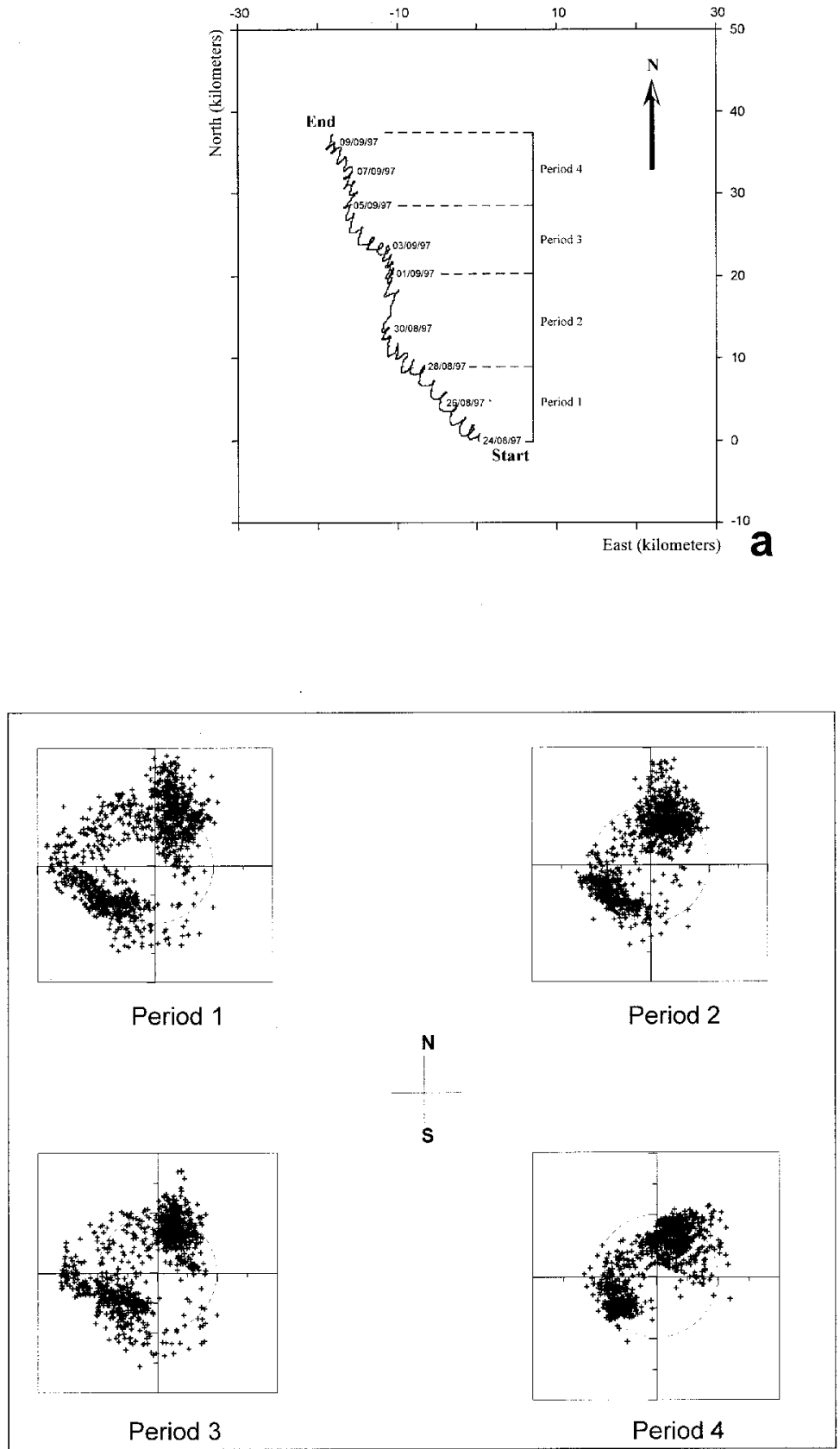

Figure 2. (a) Progressive vector diagram of the current at $3.5 \mathrm{~m}$ above the bottom and at $2 \mathrm{~m}$ from the Rainbow black smokers (Flores 5). (b) Scatter plots of the same current for each period of particle sampling. 


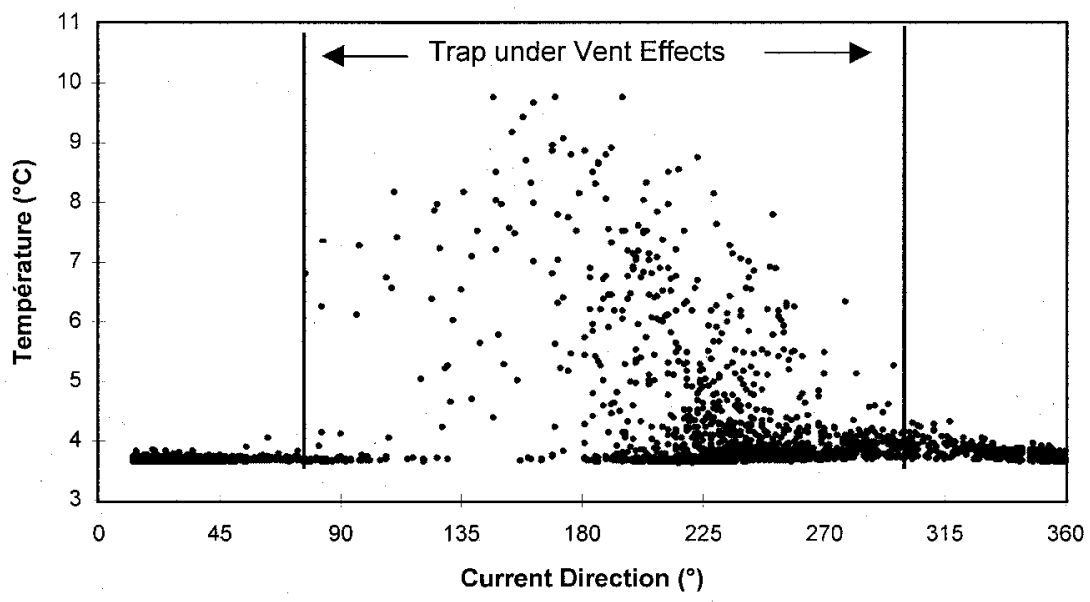

Figure 3. Temperature versus current direction recorded every 5 minutes by the current-meter $2 \mathrm{~m}$ above the $\mathrm{S}$ trap close to Rainbow vent. The area limited by the two vertical lines is the direction interval for which the trap was under the direct vent effect.

At $500 \mathrm{~m}$ northward of the Rainbow vents (M500), it was similar to the pelagic flux and varied from $11.3 \mathrm{mg} \mathrm{m}^{-2} \mathrm{~d}^{-1}$ (150 $\mathrm{m}$ a.b.) to $10.6 \mathrm{mg} \mathrm{m}^{-2} \mathrm{~d}^{-1}$ (300 $\mathrm{m}$ a.b.). At $1000 \mathrm{~m}$ (M1000), the particle flux was slightly higher than those obtained in the other traps, and equal to $17.5 \mathrm{mg} \mathrm{m}^{-2} \mathrm{~d}^{-1}$ (150 $\mathrm{m}$ a.b.) and $25.0 \mathrm{mg} \mathrm{m}^{-2} \mathrm{~d}^{-1}$ (300 $\mathrm{m}$ a.b.) (Table 2). Some trends are evident in all the traps (Fig. 6). The total fluxes decreased regularly in autumn, then remained very weak during the winter (except for a small increase in February) and finished by a peak in June. A fourth large peak appeared at M1000 in January $150 \mathrm{~m}$ a.b. and $300 \mathrm{~m}$ a.b. explaining the increase of the mean particle flux.

\section{c. Particle composition}

The main features of the vent particle composition in the $\mathrm{S}$ trap were the dominance of sulphur and calcium (as $\mathrm{CaSO}_{4}$ ), the high concentration of iron $(7 \%)$ and copper (3.5-5.5\%) and the low concentration of particulate organic carbon $(0.13 \%)$ (Fig. 5, Table 3). Inorganic carbon (carbonate) was not detected. The isotopic composition in $\delta^{15} \mathrm{~N}$ and $\delta^{13} \mathrm{C}$ (Fig. 7) of the particulate organic matter collected in the $\mathrm{S}$ trap are, respectively, $+1.9 \%$ and $-21 \%$. The major chemical elements did not show spatial or temporal fluctuations (Fig. 5b) indicating that the particle composition of the emission was homogeneous during the 16 days of experiment. 

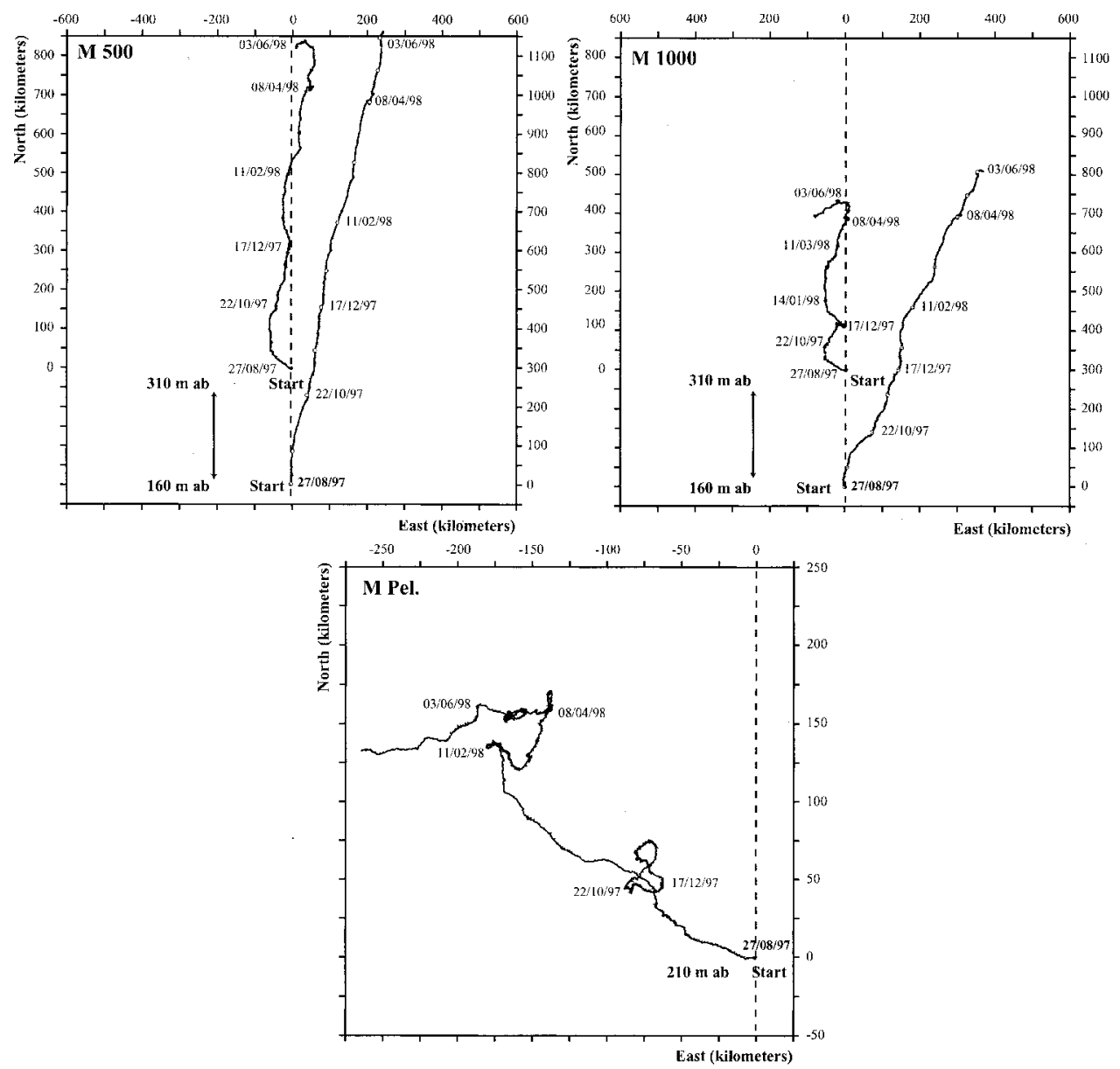

Figure 4. Progressive vector diagram of the current measured with current-meters positioned on M500, M1000 and M Pelagic moorings (Note the scale change for the M Pel. figure.)

The elemental composition of particles from the sediment traps at M Pelagic, M500 and M1000 is shown in Table 3. The organic carbon concentration varied from $4.9 \%$ to $7.3 \%$ and the organic carbon flux was regularly lower (150 m a.b.) than $300 \mathrm{~m}$ a.b. in the M500 moorings. Inorganic carbon concentration was high $(>8 \%)$ at M Pelagic, M500 (300 m) and M1000 (150 m and $300 \mathrm{~m})$ but it was clearly weak $(5.3 \%)$ at M500 (150 m). The inorganic carbon flux at M1000 and at M Pelagic did not show particular temporal variation and was always higher than at M500 (Fig. 8). The sulphur concentration (0.13-0.54\%) was low throughout the experiment at M pelagic and M1000. In contrast, particles from the M500 (150 m a.b.) were characterized by high sulphur concentrations during the first four months of the experiment (Table 3, Fig. 8). During the same period, the $\mathrm{Fe}$ and $\mathrm{Cu}$ concentrations were particularly high (respectively, 22.5 and 9.1\%) compared 
Total Flux

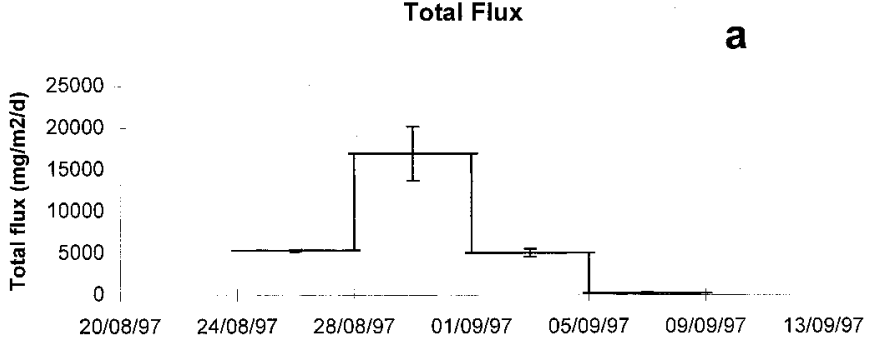

Composition

b

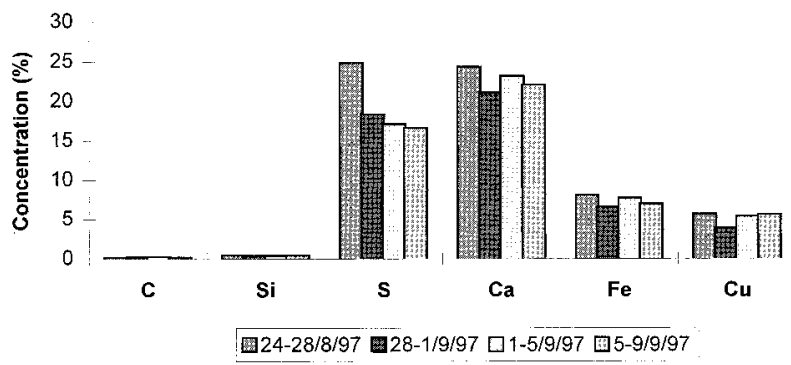

Flux of bivalve larvae

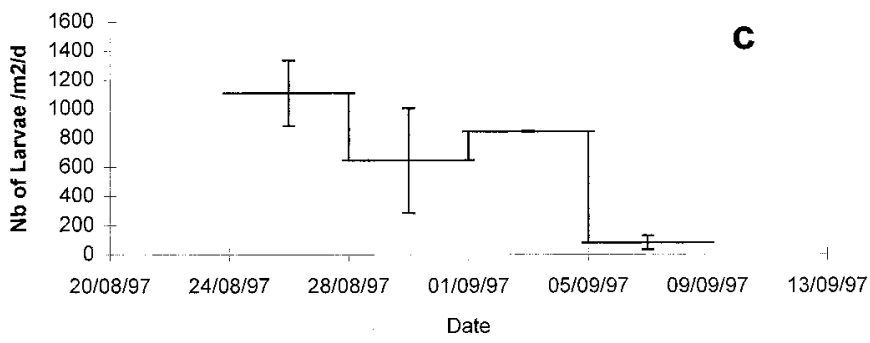

Figure 5. Total particle flux (a), particle composition (b) and larval bivalve flux (c) in the S trap (Bars represent the SD of 3 replicates).

with those measured in the other traps (Table 3). The isotopic composition in $\delta^{13} \mathrm{C}$ was similar at M500 and M1000 ( -23.5) while the M500 $(150 \mathrm{~m})$ was enriched in $\delta^{15} \mathrm{~N}$ (+4.2) in comparison with M1000 (+1.8) (Fig. 7).

\section{d. Fauna}

Numerous living organisms were present in the $\mathrm{S}$ trap moored close to the vent. Bivalve larvae belonging to the mytilid species Bathymodiolus azoricus (Comtet et al., 2000) were 
Table 2. Mean particle flux sampled in the large traps (Long-term moorings).

M Pelagic M $\quad$ M 50000

$200 \mathrm{~m}$ a.b. $\quad 150 \mathrm{~m}$ a.b. $\quad 300 \mathrm{~m}$ a.b. $\quad 150 \mathrm{~m}$ a.b. $\quad 300 \mathrm{~m}$ a.b.

$\begin{array}{llllll}\text { Mass flux }\left(\mathrm{mg} \mathrm{m}^{-2} \mathrm{~d}^{-1}\right) & 11.2 & 11.3 & 10.6 & 17.5 & 25.0 \\ \text { Organic C. }\left(\mathrm{mg} \mathrm{m}^{-2} \mathrm{~d}^{-1}\right) & 0.62 & 0.47 & 0.66 & 0.82 & 1.28 \\ \text { Inorg. C. }\left(\mathrm{mg} \mathrm{m}^{-2} \mathrm{~d}^{-1}\right) & 1.32 & 0.63 & 1.02 & 1.43 & 2.10 \\ \text { Sulphur }\left(\mathrm{mg} \mathrm{m}^{-2} \mathrm{~d}^{-1}\right) & 0.04 & 0.94 & 0.10 & 0.05 & 0.06\end{array}$

characterized by the uniform size of their shells (500 $\pm 35 \mu \mathrm{m}$ long) suggesting that they were at the same stage of development. No major difference was observed between the bivalve larvae abundance during the three first periods of sampling. However, the larvae flux strongly decreased during the last period (Fig. 5c) although the number of other organisms did not change (Table 4). A single bivalve larva of the Nuculidae family was collected in the trap. Polychaetes (23) found in the trap were essentially at the larval or juvenile stage. Gastropods (13) belonging to two vent species (Shinkailepas sp. and Phymorhynchus sp.) and two holoplanktonic species, halacarids and a single pycnogonid were also sampled in the trap S. Numerous copepods were also found in this trap (Table 4).

Benthic and planktonic organisms were collected at different stages of development in the traps M500 and M1000 (Fig. 9). Bivalves, polychaetes, gastropods, euphausiaceans and copepods (harpacticoid and calanoid copepods, nauplii) were the most common taxa. Other organisms were present in low abundance (nematodes, ostracods, amphipods, tanaids, epicarid isopods, larvae of cirripeds, ophiurids, asterids).

Bivalve larvae, belonging to the same species as the mytilid larvae found in the $S \operatorname{trap}(B$. azoricus), occurred largely at the beginning of the experiment in the trap M500, $150 \mathrm{~m}$ a.b. Only a few individuals of B. azoricus were present at M500, $300 \mathrm{~m}$ a.b. and M1000, $300 \mathrm{~m}$ a.b. Several bivalve larvae belonging to another unknown species were also found at M1000, $150 \mathrm{~m}$ a.b. No bivalve larva was present in the pelagic trap. Polychaete larvae and

Table 3. Mean chemical composition (\%) of particles sampled in the sediment traps (Only the first 4 month's results were take into account in the trap M500, $150 \mathrm{~m}$ a.b.).

M500

(\%) composition) composition) $300 \mathrm{~m}$ a.b. $150 \mathrm{~m}$ a.b. $300 \mathrm{~m}$ a.b. $200 \mathrm{~m}$ a.b.

$\begin{array}{lrrrrrr}\text { Organic C. } & 0.13 & 4.9 & 7.3 & 5.5 & 5.9 & 7.2 \\ \text { Inorganic C. } & \approx 0 & 5.3 & 8.0 & 8.4 & 8.4 & 9.0 \\ \text { Phosphorus } & 0.45 & 0.8 & 0.3 & 0.21 & 0.5 & 0.2 \\ \text { Sulphur } & 17.2 & 13 & 0.90 & 0.31 & 0.35 & 0.31 \\ \text { Calcium } & 22.6 & 13.5 & 22.7 & 21.2 & 22.6 & 22.6 \\ \text { Iron } & 7.2 & 22.5 & 2 & 0.83 & 0.84 & 0.58 \\ \text { Copper } & 5.0 & 9.1 & 0.59 & 0.45 & 0.41 & 0.33 \\ \text { Silica } & 0.35 & 3.8 & 7.1 & 6.44 & 7.2 & 7.21\end{array}$



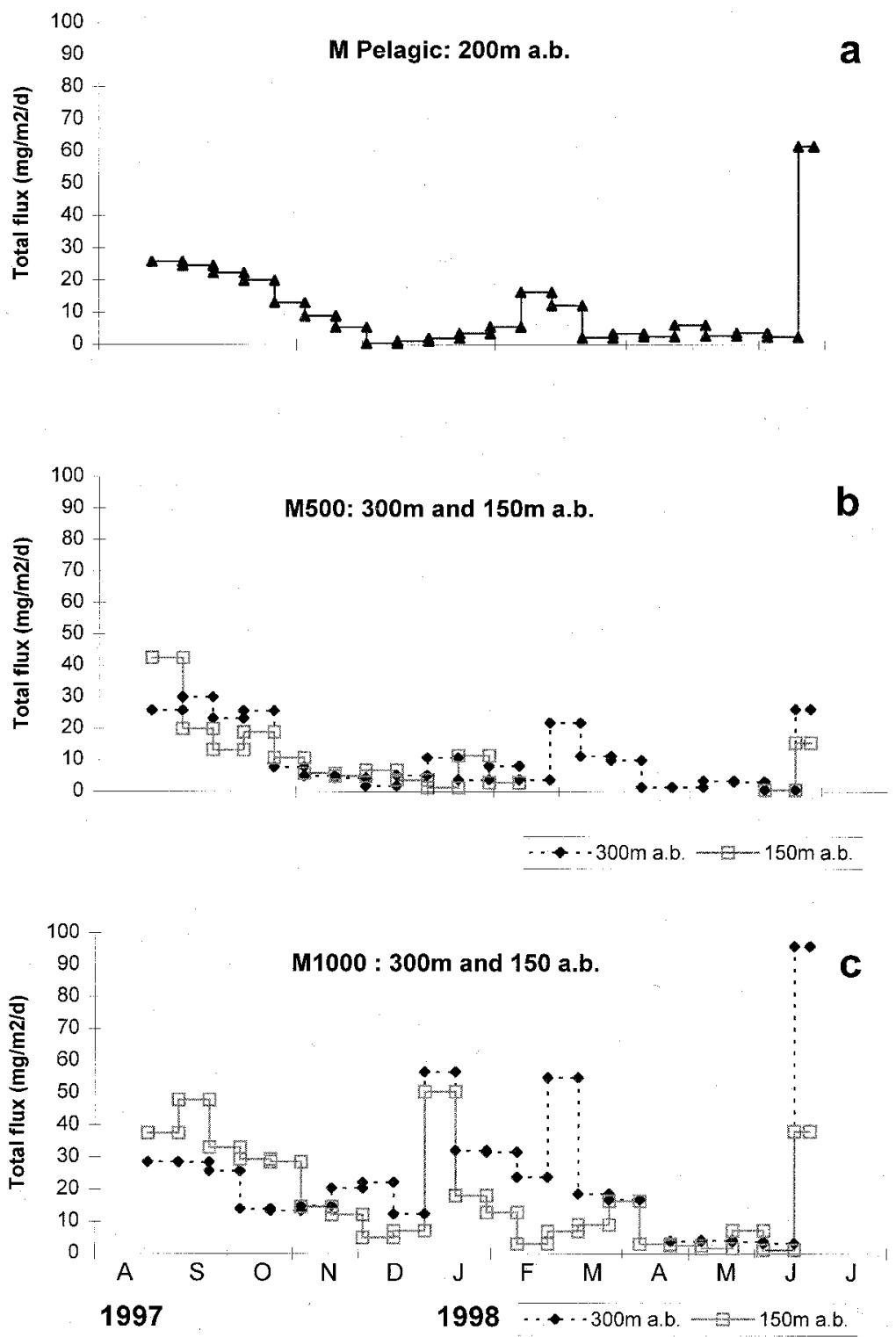

Figure 6. Temporal variation of total flux measured with traps positioned on the M Pelagic (a), M500 (b) and M1000 (c) moorings.

juveniles belonging to several families (Spionidae, Hesionidae, Glyceridae, Syllidae, Poecilochaetidae, Polynoidae, Aphroditidae, Archinomidae, Ophelidae, Typhloscolecidae) were also observed in all traps. Only one polychaete Archinomidae, unequivocally belonging to the hydrothermal fauna, was sampled in the trap M500, $150 \mathrm{~m}$ a.b. Gastropod 


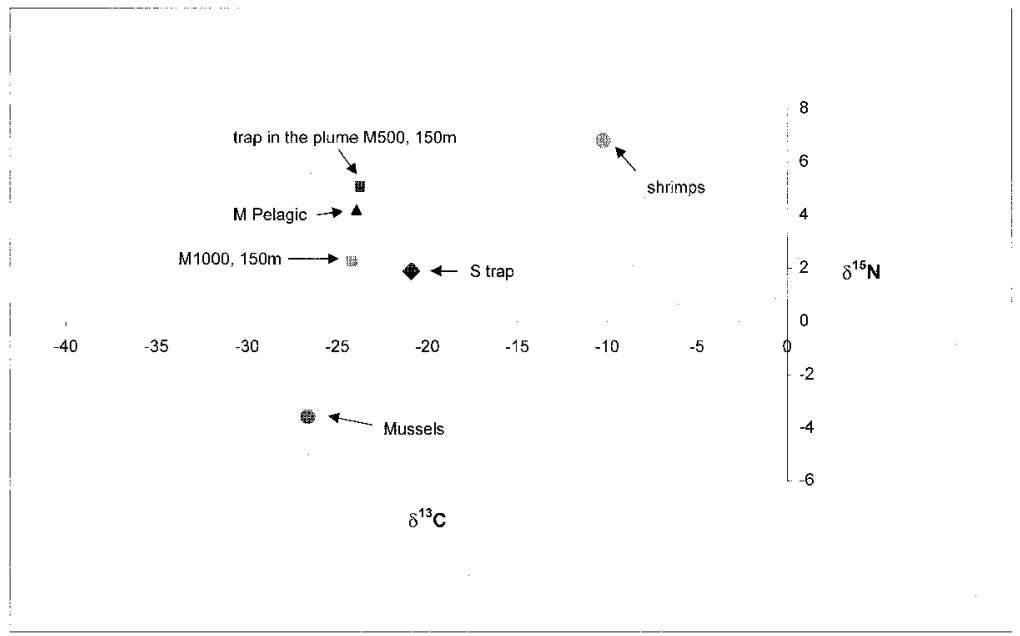

Figure 7. Isotopic composition of the sediment trap material and the organisms (Colaço, 2001) from Rainbow vent field.
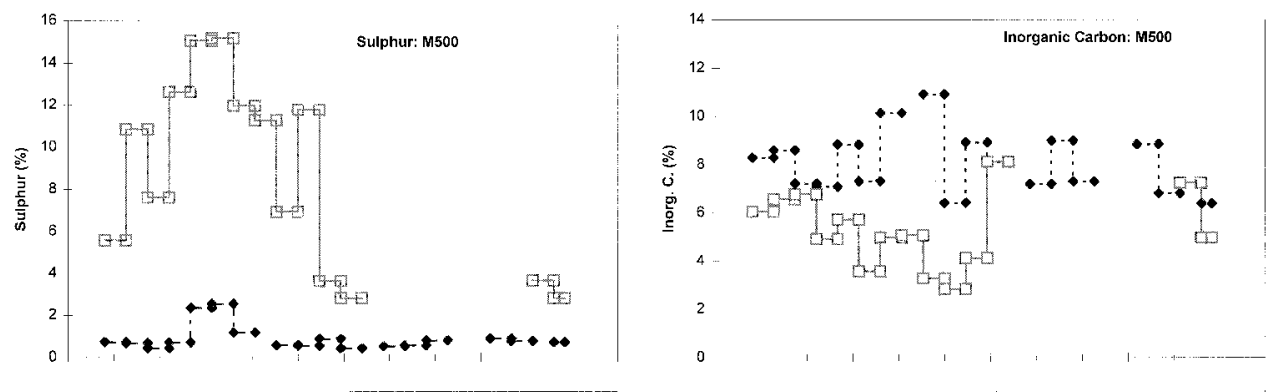

- $-300 \mathrm{~m}$ a.b. $-9-150 \mathrm{~m}$ a.b.
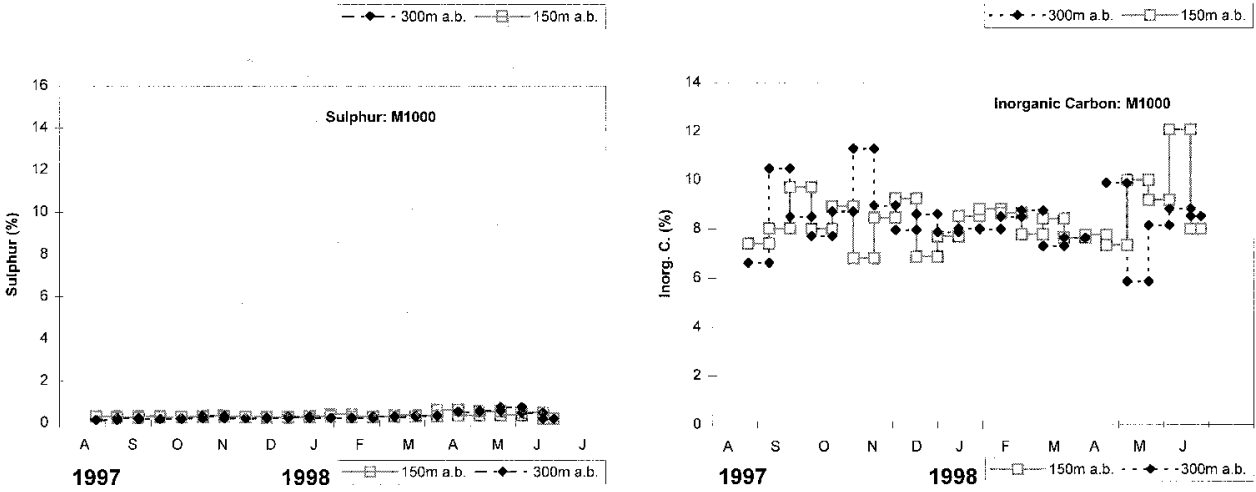

Figure 8. Temporal variation of the particle composition in the traps positioned on the M500, M1000 and M Pelagic moorings. 
Table 4. Number (min-max) of living animals collected close to the Rainbow vent in the S trap.
Dates
Bivalves
Polychaetes
Gastropods
Copepods

(24/08/97-28/08/97)

28/08/97-01/09/97

$\begin{array}{cc}249-355 & 0-3 \\ 59-302 & 2-5 \\ 80-237 & 0-5 \\ 4-32 & 0-2\end{array}$

$1-5$

30-53

$01 / 09 / 97-05 / 09 / 97$

$2-5$

0-3

$13-52$

05/09/97-09/09/97

$0-2$

0-2

30-38

0-2

12-27

larval abundance (two benthic species) did not exhibit a temporal trend over the collection period. Juvenile euphausids, belonging to the genus Thysanoessa, were observed in high abundance between August to December 1997 in the traps M500, 300 m a.b., M1000 $150 \mathrm{~m}$ and $3000 \mathrm{~m}$ a.b., but they were rare in the trap M500 (150 m a.b.) and in the pelagic trap (Fig. 9).

\section{Discussion}

a. Pelagic flux in the Rainbow area

The Pelagic trap, positioned $2 \mathrm{~km}$ away from the ridge axis, was taken as a reference for the background flux not influenced by the hydrothermal vents. The mean particle flux
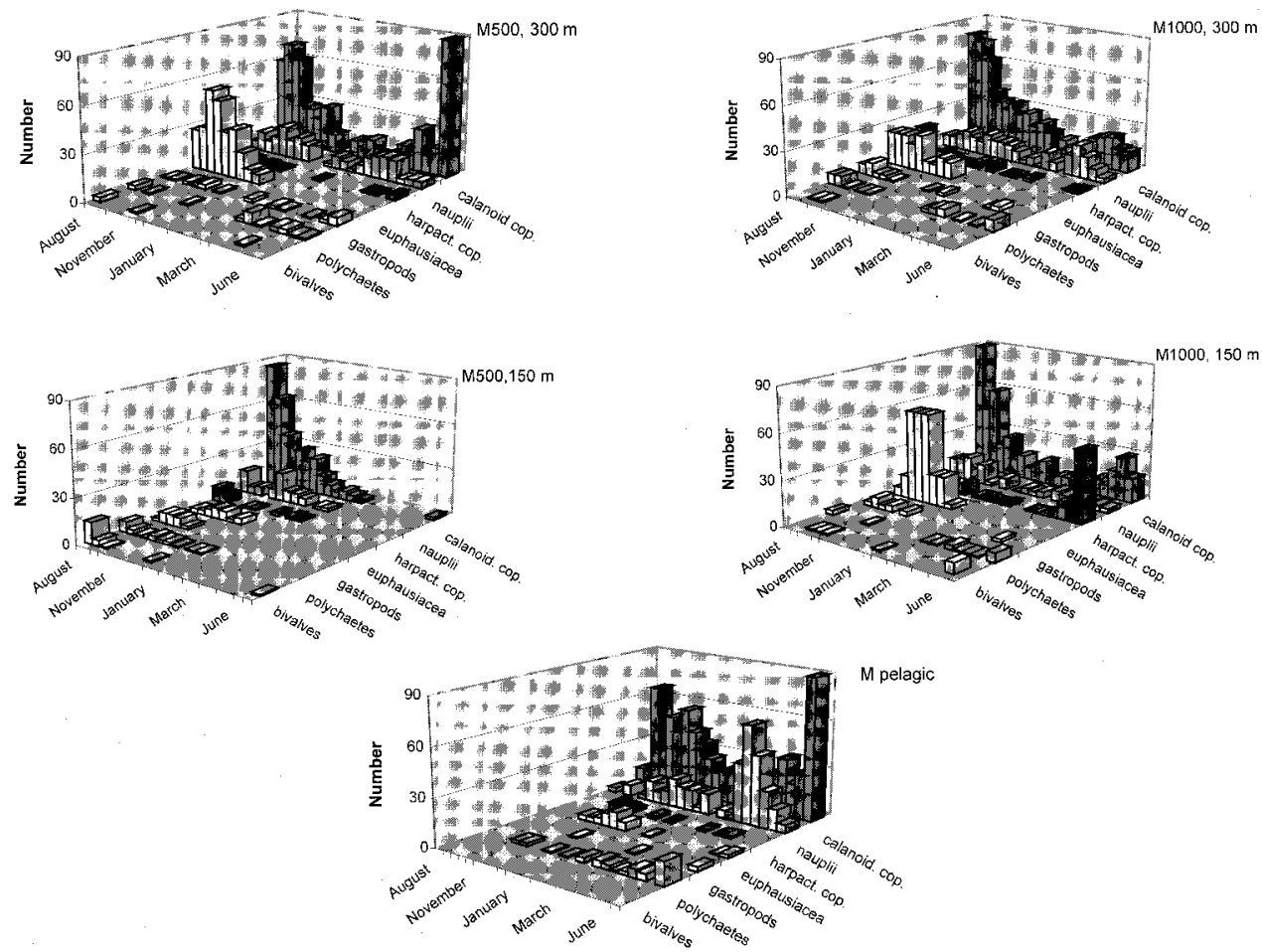

Figure 9. Temporal variations of common taxa sampled with the M500, M1000 and M Pelagic traps. 
(11.2 $\left.\mathrm{mg} \mathrm{m}^{-2} \mathrm{~d}^{-1}\right)$, measured with this trap, was comparable to the flux obtained on the Lucky Strike area in the Azores region (7.7 $\mathrm{mg} \mathrm{m}^{-2} \mathrm{~d}^{-1}$, Khripounoff et al., 2000). These fluxes are among the lowest recorded in the oligotrophic Atlantic Ocean (Honjo and Manganini, 1993; Deuser, 1986; Auffret et al., 1994; Khripounoff et al., 1998). This result is in agreement with the very low primary production in the Azores region observed by Angel (1989). The relatively high $\delta^{15} \mathrm{~N}$ of material collected in the Pelagic trap (Fig. 6) is consistent with the presence of plankton detritus from oligotrophic, nitrate-poor environments (Holmes et al., 1996; Waser et al., 1998).

The particulate flux coming from the surface showed large fluctuations typical of deep-sea environments with pronounced seasonal changes (Honjo and Manganini, 1993; Newton et al., 1994), with a maximum observed in June due to the spring bloom of the surface primary production and a minimum in winter. The very low concentration of typical hydrothermal compounds $(\mathrm{S}, \mathrm{Fe}, \mathrm{Cu})$ in the particles and the absence of hydrothermal fauna confirm that the pelagic trap was not under the direct effect of the vents. The high organic carbon concentration indicates the freshness of the pelagic origin particles.

\section{b. Particles emitted by the Rainbow vents}

The particle flux in the Rainbow vent area (average $6.9 \mathrm{~g} \mathrm{~m}^{-2} \mathrm{~d}^{-1}$ ) was 500 times higher than that at the pelagic site. A similar high flux was observed close to the East Pacific Rise hydrothermal vent fields using the same sampling technique (Khripounoff and Alberic, 1991) and the Endeavour Ridge (2200 m) (Roth and Dymond, 1989). On the Mid-Atlantic Ridge, the Rainbow vent emitted a comparable flux as on the TAG site (3680 m) (9.0 $\mathrm{g} \mathrm{m}^{-2} \mathrm{~d}^{-1}$ : Desbruyères et al., 2000) but was significantly higher than that measured at Menez Gwen $(850 \mathrm{~m})\left(0.64 \mathrm{~g} \mathrm{~m}^{-2} \mathrm{~d}^{-1}\right.$, Desbruyères et al., 2001) and Lucky Strike (1600 m) (0.26 g m $\mathrm{g} \mathrm{d}^{-1}$, Khripounoff et al., 2000). At Rainbow, in common with TAG and Pacific vents, active black smokers emit dark, particle-rich fluid, while the shallow vents such as Lucky Strike and Menez-Gwen emit translucent fluid with low particle content. These high differences in particle production result from differences in fluid chemistry which depends on the temperature and pressure conditions met during hydrothermal circulation (Douville et al., 1999). Phase separation events due to the shallow depth at Menez-Gwen and Lucky Strike (resulting in a low metal concentration in the fluid) and the extensive alteration of the basaltic substrate explain the low particle production at these shallower stations (Klinkhammer et al., 1995; Wilson et al., 1996).

In addition, the amount of particles collected in the trap also depends on the trap position relative to the chimney and on the current direction. The occurrences of the temperature anomalies $>4{ }^{\circ} \mathrm{C}$ (Fig. 3) indicate that the trap was directly under the chimney influence during approximately $11 \%$ of the time without regular temporal trend (Fig. 3). This relatively low percentage is easily explainable by the position of the trap (south) in relation to the black smokers and the main current direction (northeast). The current varied very little in direction and speed (Fig. 2) and the hydrodynamic conditions were very similar during the different periods of particle sampling. The strong fluctuations of the particulate 
flux during the 16 days of experiment (Fig. 5) were likely, therefore, the result of irregular fluid production rather than current variations. Temporal changes in vent production have been reported at other hydrothermal sites over time scales of minutes (Converse et al., 1984), hours (Chevaldonné et al., 1991) and weeks (Murton and Redbourn, 1997). For Chevaldonné et al. (1991), aperiodic variability of temperature observed in different vents can be explained by a change in the plumbing of the porous diffusive system in the chimney, which can explain also the variation of the particle flux emission.

The elemental composition of the particles sampled near the vent (Table 2) was characterized by a high sulphur concentration $(S>17 \%$ ) of which the main origin was the hydrothermal fluid precipitation. The particulate sulphur content at Rainbow was slightly higher than that measured near the Lucky Strike vents (11\%) (Khripounoff et al., 2000) and similar to the sulphur concentration at Menez-gwen (18.2\%) (Desbruyères et al., 2001). But it was lower than that observed close to the Pacific vents ( $\mathrm{S} \geq 25 \%$ ) (Dymond and Roth, 1988; Khripounoff and Alberic, 1991). One of the main features of the Rainbow vent composition is the high concentration of $\mathrm{Cu}(3.6 \%)$, which is consistent with the fluid composition (Douville et al., 1997). The $\delta^{13} \mathrm{C}$ composition of the sediment trap materials was quite different from that of the mussel and shrimp adults collected on the bottom on the Rainbow site (Fig. 7, Colaço et al., 2001). $\delta^{13} \mathrm{C}(-24 \%$ o) in the sediment traps was more depleted than in the hydrothermal shrimps $(-10 \%$ ). Mussels (B. azoricus) tend to have more negative $\delta{ }^{13} \mathrm{C}$ values and are much more depleted in $\delta{ }^{15} \mathrm{~N}$. These significant differences suggest that the hydrothermal mussels did not directly consume the organic particulate material emitted by the vents although these organisms demonstrate filtering behavior (Le Pennec et al., 1990).

\section{c. Export of hydrothermal particles to the surrounding ocean}

Vent particle export to the surrounding area depends first on the speed and the direction of the local current. To know when the vent particle transport was favorable to the traps at $500 \mathrm{~m}$, the percentage of instantaneous current flowing in the right direction has been computed for each particle-sampling interval. The favorable direction has been chosen as $21^{\circ}$, corresponding to the direction of Rainbow vents to the M500, plus an angle of $20^{\circ}$ on each side (to take into account the diffusion). The minimum speed required to cover the vent-trap distance is equal to $500 \mathrm{~m} / 3 \mathrm{~h}$ (half time of the tidal current reverse) $=$ $4.6 \mathrm{~cm} \mathrm{~s}^{-1}$. Figure 10 shows the result of this empirical estimation versus time. For the duration of the sampling, the current was favorable for transporting vent particles to the M500 during 36\% of the time on average at $150 \mathrm{~m}$ a.b. and $22 \%$ at $300 \mathrm{~m}$ a.b. The result of this favorable current orientation has been that sulphur, as a hydrothermal chemical signature, was found in large quantity $(\max =15 \%)$ during the first four months of the experiment in the trap M500 at $150 \mathrm{~m}$ a.b. and also at $300 \mathrm{~m}$ a.b. with a lower concentration (Fig. 8). This result indicates that the correct orientation of the current from the vents to the traps is necessary in order to sample hydrothermal material in this equipment. However, Figure 10 shows that the favorable direction of the current is not the 

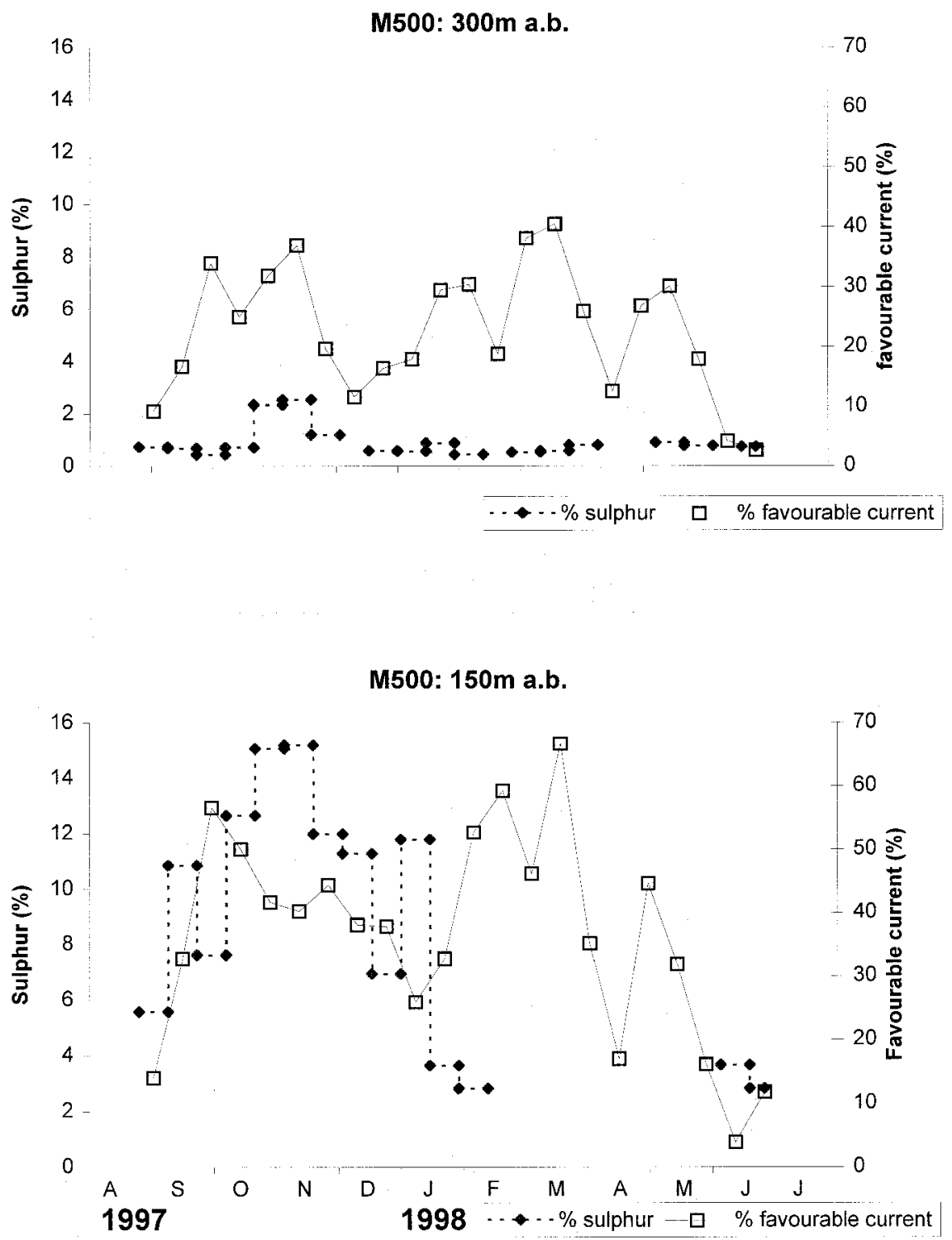

Figure 10. Temporal variations of sulphur concentration in the particles and percentage of instantaneous current flowing in the right directions from the vents toward the mooring M500.

only parameter required to capture hydrothermal particles in the traps with certainty. The sulphur concentration, derived from the plume, showed large temporal fluctuations in the trap $150 \mathrm{~m}$ a.b. without direct relationship with our estimation of the right current direction percentage (Fig. 10). This observation suggests variations either in the altitude of the plume (the plume flowed irregularly under the lower trap, $150 \mathrm{~m}$ a.b.) or in the particle 
emission by the vents on the scale of few days, or modifications of the plume vertical expansion. Multi-peaked plumes (German et al., 1996; Thurnherr and Richards, 2001) indicate that the plume vertical structure might change with the time and that the plume horizontal extent might be compared to patches of particle rich fluid (Thurnherr and Richards, 2001). We observe that the sulphur concentration was low in the trap moored at the upper limit of the plume (300 $\mathrm{m}$ a.b.). It corresponds generally to sulphur background variability observed in the pelagic particles with a notable exception in November when the maximum (3\%) corresponds to the maximum found in the trap $150 \mathrm{~m}$ a.b. (Fig. 10). No evident relationship exists between the sulphur concentration at $300 \mathrm{~m}$ a.b. and the current direction at this altitude. Finally, the complete absence of an expected variation in temperature measured with the thermistor chain can be explained by the rapid fluid dilution and only the background variability of the seawater temperature was measured masking the hydrothermal signal (Wilson et al., 1995; Thurnherr and Richards, 2001).

Although the trap M500, $150 \mathrm{~m}$ a.b. was significantly enriched with particles from the plume at the beginning of the experiment, the total mass flux measured with this trap did not differ from the pelagic flux measured over the same period (Table 2). This discrepancy can be explained if the trap M500, $150 \mathrm{~m}$ a.b. did not receive the totality of the pelagic flux. Assuming that the vent particles did not contain inorganic carbon (no inorganic carbon was measured in the $\mathrm{S}$ trap), the estimation of the relative contribution of pelagic particles to the total mass flux at $150 \mathrm{~m}$ a.b. for trap M500 during the plume sampling (first four months) is:

$$
\frac{\text { Inorg.C.flux, M500 }}{\text { Inorg.C.flux, MPelagic }} \times 100=48 \% \text {. }
$$

The particle composition in the plume consisted of only $48 \%$ of pelagic particles (52\% of hydrothermal particles). The same calculation indicates that this ratio was near $100 \%$ in the trap $300 \mathrm{~m}$ a.b. The main factor, which may account for the low abundance of pelagic particles in the plume, is that the plume had not reached its altitude of neutral buoyancy (iso-density). The result was a discontinuity which disrupted the settling of particles into the plume water (umbrella effect). The multi-peaked plumes observed by German et al. (1996) and Thurnherr and Richards (2001) at Rainbow imply different plume densities with different heights of rise and possible different composition which sorts pelagic particles. In addition, there may have been some dissolution of the pelagic carbonates by the acidic plume water. This acidification could be the result of the very acid fluid origin of the plume water or of the high bacteria activity on the plume particles (McCollom, 2000).

Chemical behavior of major elements in hydrothermal plumes has generally been found to show an enrichment of $\mathrm{Fe}$ oxides and a decrease of sulphide particles. In comparison to the initial conditions of emission ( $\mathrm{S}$ trap), the increase of $\mathrm{C}, \mathrm{Fe}, \mathrm{Cu}$ and the decrease of $\mathrm{S}$ and $\mathrm{Ca}$ in the trap M500, $150 \mathrm{~m}$ a.b. confirms these chemical modifications during the plume transport (Table 3). The high concentration of $\mathrm{Fe}$ is a characteristic of the neutrally buoyant plume at Rainbow (Edmonds and German, 2001) and apparently results from $\mathrm{Fe}$ 
hydroxide formation and lesser sedimentation of Fe sulfides as compared with other vent sites (Douville et al., 1997). The increase of $\mathrm{Ca}$ and $\mathrm{C}$ results from the presence of the pelagic particles in the plume (see above). The large decrease of $\mathrm{S}$ indicates rapid settling of this element (as sulfide) near the emission site and dilution of the plume particles with the pelagic particles. The $\delta^{15} \mathrm{~N}$ enrichment in the particles from M500, $150 \mathrm{~m}$ a.b. suggests that the organic compounds of the plume are composed by mixing of particles from different origins with a dominance of the pelagic organic particles. The $\delta^{13} \mathrm{C}$ composition, which overlaps with the one reported for phytoplankton from temperate regions (Fontugne and Duplessy, 1981), confirms this observation.

The same calculation at M1000 as at M500 (see above) of the percentage of instantaneous current flowing in the right direction indicates that the current was in the favorable direction during $9 \%$ of the time (the parameters chosen for this estimation are: current direction $38^{\circ} \pm 20^{\circ}$, minimum speed $1000 \mathrm{~m} / 3 \mathrm{~h}=9.2 \mathrm{~cm} \mathrm{~s}^{-1}$ ). This low percentage could be enough to explain the absence of hydrothermal signature (sulphur anomaly) in the M1000 traps. However, a small increase of $\mathrm{Fe}-\mathrm{Cu}$ (Table 2) was observed compared with our reference (M pelagic). But the low accuracy of our measurements made with the $\mathrm{X}$ ray spectrometry for these elements (due to weak concentrations) makes the confirmation of the hydrothermal particle presence in these sediment traps difficult. Other possibilities can also explain this lack of significant hydrothermal signal. The dilution of the plume at $1 \mathrm{~km}$ from the vents was too great for it to be detected in the trap. But this explanation is insufficient because German et al. (1996) and German et al. (1998) found that particles in the plume, observed by nephelometry, could reach greater distances $(50 \mathrm{~km})$. The second hypothesis is that the neutrally buoyant plume passed over the upper trap (300 m) and did not produce settling particles at this altitude. This explanation seems unlikely because Thurnherr and Richards (2001) indicate a maximum plume elevation of $400 \mathrm{~m}$ at a distance of $1 \mathrm{~km}$ from the vents and the plume thickness exceeds several hundred meters (German et al., 1998). The other possibility is that the traps were regularly in the plume but the large hydrothermal particles, rich in sulphur, settled before reaching the traps or their concentration was too weak to be detected in the samples at this distance. This explanation is consistent with the strong decrease of sulphur concentration observed in this study between the particles in the $S$ trap and the particles in M500 traps. The size distribution of suspended particles in neutrally buoyant hydrothermal plumes rich in $\mathrm{Fe}$ is characterized by the dominance of particles with very small diameter (Walker and Baker, 1988; German and Sparks, 1993). These observations suggest that, even if the plume particle density is high, the settling could be very slow and the plume particle flux measured at $1000 \mathrm{~m}$ represents only a small fraction of the regional pelagic flux. The $\delta^{13} \mathrm{C}$ composition at M1000, which was similar to the value obtained from the pelagic trap, confirms the prevalence of the organic material from the pelagic flux at this distance. The depletion in term of $\delta^{15} \mathrm{~N}$ at M1000 compared with the pelagic material can be the result of different rates of bacterial degradation which produces a variation in the $\delta^{15} \mathrm{~N}$ (Altabet and McCarthy, 1986) or of the influence of the particle sizes (Altabet, 1988). 


\section{d. Fauna}

The sediment traps, designed for the study of particle flux in the ocean, proved to be a particularly well-adapted tool to the collection and the observation of small living organisms. In this study, the sampled fauna varied greatly with the time and between traps located at different distances from the vents (Fig. 5 and 9). The occurrence of high densities of hydrothermal vent mytilid populations (identified as B. azoricus, Comtet et al., 2000) in the $\mathrm{S}$ trap at the Rainbow site suggests that they originated from the mussel beds observed $120 \mathrm{~m}$ to the southwest. The majority of the larvae shells were of similar size, indicating a similar stage of development. This implies that the larvae may have stayed on the site over a long time (3-6 weeks if we compare with the larvae development duration of the shallow mussel Mytilus edulis). The very high density of bivalve larvae in the $\mathrm{S}$ trap was due to the existence of retention factors. Vent larvae may remain aggregated because they have a positive chemosensory response to sulfides (Renninger et al., 1995). Alternatively, the hydrodynamic turbulence (vortex) produced by the active black smokers, could concentrate larvae around the trap and increase their residence time near the vent (Mullineaux and France, 1995). The bivalve larvae flux decreased significantly (Anova: $p<0.05$ ) at the end of August (Fig. 5) probably due to the strong decrease of the particle flux at this period and to the spatial heterogeneity of the organism distribution around the vent. However, the hypothesis of a discontinuous (seasonal?) mytilid reproduction cannot be dismissed (Comtet and Desbruyères, 1998). Its starting signal could be the peak of particle flux during the spring bloom in surface waters. Although a lot of bivalve larvae were found around the vent, the black smokers were nearly azoic in August 1997 (Marvel cruise) and one year later, in June 1998 (Pico cruise). The development of mussels around the black smokers was hindered by the very high flux of mineral particles which can affect the water filtration and also juvenile growth (Bricelj et al., 1984). In contrast, the common holoplankton groups, such as the copepods, were clearly more abundant in the trap closer to the vents than in the traps moored far away. Their prevalence near the vents suggests that they found a local nutrient enrichment and it appears that they are highly tolerant to reduced compounds and heavy metals present in the hydrothermal fluids. These groups may be specifically associated with vent habitats (Kim and Mullineaux, 1998).

Bivalve larvae were also caught in the trap M500 (150 $\mathrm{m}$ a.b.). Temporal difference in abundance of these organisms, belonging to the hydrothermal species B. azoricus, was found with a maximum of larvae in summer, suggesting again a discontinuous hydrothermal bivalve reproduction, in agreement with our results obtained with the trap S moored near the vent. The presence of few individuals of the same species in the M1000 traps (but not in the pelagic trap) indicates that the hydrothermal plume is able to transport few small organisms, at least a kilometre from the vent site, and to disperse the vent species along the mid-ocean ridge (Kim et al., 1994; Mullineaux and France, 1995).

Previous studies have highlighted that zooplankton biomass often increases near the hydrothermal fields (Berg and Van Dover, 1987; Burd and Thomson, 1994; Kaartvedt et al., 1994; Mullineaux et al., 1995; Herring and Dixon, 1998). The presence of high 
euphausiacean density in the traps moored in the rift valley in comparison with the pelagic trap confirms this rise. The water nutrient enrichment, due to an abundance of free-living bacteria supporting the hydrothermal trophic food web, is the common explanation for this biomass increase (McCollom, 2000). The depletion of $\delta^{15} \mathrm{~N}$ in the traps moored in the rift (Fig. 6) is an indication of local organic matter production in the valley which was also confirmed by the increase of organic carbon flux in the M1000 traps (Table 3). This local modification of the food web creates a new environment which facilitates the zooplanktonic congregation (Vereshchaka and Vinogradov, 1999). Burd et al. (1992) and Burd and Thomson (1995) suggest that several zooplanktonic taxa (like the euphausiaceans in this study) may approach the plume closely, but the water toxicity prevents them from living within the plume. This hypothesis can explain the very low density of euphausiaceans found in the trap at M500, $150 \mathrm{~m}$ a.b. On the contrary, other zooplanktonic groups, like copepods, seem insensitive to this toxicity problem (see above results from the $\mathrm{S}$ trap).

\section{Conclusions}

The hydrothermal particle production and transport at Rainbow have been shown to be controlled firstly by the variation of fluid emission and then by the current direction depending on the topography of the rift valley. The results presented in this work provide important information on the particle production close to the vents and on the dispersion of the hydrothermal plume. Hydrodynamical study and biochemical analyses of the particles form the basis of a detailed description of the hydrothermal Rainbow area. For closer investigation, several studies would have to be improved. Long-term particle sampling close to a vent should provide definite proof of the irregular emission of vent fluids and the possible discontinuous reproduction of some hydrothermal organisms. Because our knowledge of the water circulation is now well documented for the Rainbow area, it will allow us to define the best position for the mooring of instruments in the future to measure the dispersion and the composition of the plume and the consequences for faunal distribution. In conclusion, the Rainbow site offers an ideal natural laboratory to study hydrothermal processes.

Acknowledgments. We would like to thank the officers and the crews of the French N/O Atalante and the German R/V Poseidon during the Marvel and Flame 2 cruises and the chief scientists, A.-M. Alayse (IFREMER) and C. German (Southampton Oceanography Centre). The authors thank T. Comtet, B. Casanova, P. Bouchet and A. Waren for providing collaboration and zoological determinations. We also acknowledge the thoughtful comments of three anonymous reviewers. This research was undertaken in part in the framework of the AMORES project. We acknowledge the support from the European Commission's Marine Science and Technology Programme (MAST 3) under contract MAST3-CT95-0040.

\section{REFERENCES}

Altabet, M. A. 1988. Variations in nitrogen isotopic compositions among particle classes: Implication for particle transformation and flux in the open ocean. Deep-Sea Res., 35, 535-554. 
Altabet, M. A. and J. J. McCarthy. 1986. Vertical patterns in $15 \mathrm{~N}$ natural abundance in PON from the surface waters of several warm core rings in the Sargasso Sea. J. Mar. Res., 44, 185-201.

Angel, M. V. 1989. Vertical profiles of pelagic communities in the vicinity of the Azores Front and their implications to deep ocean ecology. Prog. Oceanogr., 22, 1-46.

Auffret, G., A. Khripounoff and A. Vangriesheim. 1994. Rapid post-bloom resuspension in the North-Eastern Atlantic. Deep-Sea Res., 41, 925-939.

Berg, C. J., Jr. and C. L. Van Dover. 1987. Benthopelagic macrozooplankton communities at and near deep-sea hydrothermal vents in the eastern Pacific Ocean and the Gulf of California. Deep-Sea Res., 34, 379-401.

Bricelj, V. M., R. E. Malouf and C. De Quillfeldt. 1984. Growth of juvenile Mercenaria mercenaria and the effect of resuspended bottom sediments. Mar. Biol., 84, 167-173.

Burd, B. J. and R. E. Thomson. 1994. Hydrothermal venting at Endeavour Ridge: effect on zooplankton biomass throughout the water column. Deep-Sea Res. I, 41, 1407-1423.

1995. Distribution of zooplanktonassociated with the Endeavour Ridge hydrothermal plume. J. Plankton Res., 17, 965-997.

Burd, B. J., R. E. Thomson and G. S. Jamieson. 1992. Composition of a deep scattering layer overlying a mid-ocean ridge hydrothermal plume. Mar. Biol., 113, 517-526.

Chevaldonné, P., D. Desbruyères and M. Le Haître. 1991. Time-series of temperature from three deep-sea hydrothermal vent sites. Deep-Sea Res., 38, 1417-1430.

Colaço, A., F. Dehairs, A. Colaço and D. Desbruyeres. 2001. Nutritional relations of deep-sea hydrothermal fields at the Mid-Atlantic Ridge: a stable isotope approach. Mar. Ecol. Prog. Ser. (submitted).

Comtet, T. and D. Desbruyères. 1998. Population structure and recruitment in mytilid bivalves from the Lucky Strike and Menez Gwen hydrothermal vent areas $\left(37^{\circ} 17^{\prime} \mathrm{N}\right.$ and $37^{\circ} 50^{\prime} \mathrm{N}$ on the Mid-Atlantic Ridge). Mar. Ecol. Prog. Ser., 163, 165-177.

Comtet, T., D. Jollivet, A. Khripounoff, M. Segonzac and D. R. Dixon. 2000. Molecular and morphological identification of Bathymodiolus azoricus (Bivalvia: Mytilidae) in situ-preserved in sediment traps at Rainbow hydrothermal vent field (Mid-Atlantic Ridge). Limnol. Oceanogr., 45, 1655-1661.

Converse, D. R., H. D. Holland and J. M. Edmond. 1984. Flow rates in the axial hot springs of the East Pacific Rise $(21 \mathrm{~N})$ : Implications for the heat budget and the formation of massive sulfide deposits. Earth Planet. Sci. Lett., 69, 159-175.

Desbruyères, D., A. Almeida, M. Biscoito, T. Comtet, A. Khripounoff, N. Le Bris, P. M. Sarradin and M. Segonzac. 2000. A review of the distribution of hydrothermal vent communities along the Northern Mid Atlantic Ridge: Dispersal vs. environmental controls. Hydrobiologia, 440, 201-216.

Desbruyères, D., M. Biscoito, J. C. Caprais, A. Colaço, T. Comtet, P. Crassous, Y. Fouquet, A. Khripounoff, N. Le Bris, K. Olu, P. M. Sarradin, M. Segonzac and A. Vangriesheim. 2001. Variations in deep-sea hydrothermal vent communities on the Mid-Atlantic Ridge when approaching the Azores plateau. Deep-Sea Res., 1, 48, 1325-1346.

Deuser, W. G. 1986. Seasonal and interannual variations in deep-water particle fluxes in the Sargasso Sea and their relation to surface hydrography. Deep-Sea Res., 33, 225-246.

Douville, E., J.-L. Charlou, J.-P. Donval, D. Hureau and P. Appriou. 1999. Le comportement de l'arsenic (As) et de l'antimoine ( $\mathrm{Sb}$ ) dans les fluides provenant de différents systèmes hydrothermaux océaniques. C. R. Acad. Sci. Paris, Sér. II, 328, 97-104.

Douville, E., J. L. Charlou, J. P. Donval, J. Knoery, Y. Fouquet, P. Bienvenu and P. Appriou. 1997. Trace elements in fluids from the new Rainbow hydrothermal field ( $\left.36^{\circ} 14^{\prime} \mathrm{N}, \mathrm{MAR}\right)$ : a comparison with other Mid-Atlantic fluids. Eos Trans. Am. Geophys. Union, 78, 832.

Dymond, J. and S. Roth. 1988. Plume dispersed hydrothermal particles: A time-series record of settling flux from the Endeavour Ridge using moored sensors. Geochim. Cosmochim. Acta, 52, 2525-2536. 
Edmonds, H. N. and C. R. German. 2001. Particle geochemistry and cycling in the Rainbow hydrothermal plume. Geochim. Cosmochim. Acta, (submitted).

Elderfield, H. and A. Schultz. 1996. Mid-ocean ridge hydrothermal fluxes and the chemical composition of the ocean. Ann. Rev. Earth Planet. Sci., 24, 191-224.

Emery, W. J. and R. E. Thomson. 1998. Data Analysis Methods in Physical Oceanography, Pergamon, London, 634 pp.

Feely, R. A., J. H. Trefry, G. T. Lefon and C. R. German. 1998. The relationship between P/Fe and $\mathrm{V} / \mathrm{Fe}$ ratios in the hydrothermal precipitates and dissolved phosphate in seawater. Geophys. Res. Lett., 25, 2253-2256.

Fontugne, M. R. and J. C. Duplessy. 1981. Organic carbon isotopic fractionation by marine plankton in the temperature range -1 to $31^{\circ}$. Oceanol. Acta, 4, 85-90.

Fouquet, Y., J.-L. Charlou, J.-P. Donval, J. Radford-Knoëry, H. Ondréas, P. Cambon, H. Bougault, J. Etoubleau, F. Barriga, I. Costa, N. Lourenço and M. K. Tivey. 2001. Hydrothermal processes on shallow volcanic segments: Mid-Atlantic Ridge near the Azores Triple Junction. J. Geophys. Res., (submitted).

Fouquet, Y., J.-L. Charlou, H. Ondréas, J. Radford-Knoëry, J.-P. Donval, E. Douville, R. Apprioual, P. Cambon, H. Pelé, J. Y. Landuré, A. Normand, E. Ponsevera, C. R. German, L. Parson, F. Barriga, I. Costa, J. Relvas and A. Ribeiro. 1997. Discovery and first submersible investigations on the Rainbow hydrothermal field on the MAR ( $\left.36^{\circ} 14 \mathrm{~N}\right)$. Eos Trans. Am. Geophys. Union, 78, 832.

German, C. R., G. P. Klinkhammer and M. D. Rudnicki. 1996. The Rainbow hydrothermal plume. $36^{\circ} 14^{\prime}$ N. Mid-Atlantic Ridge. Geophys. Res. Lett., 23, 2979-2982.

German, C. R., K. Richards, M.-M. Lam, A. Thurnherr, P. J. Baptiste, A.-M. Le Clerc, A. Dapoigny, M. Cooper, M. Rudnicki, H. Elderfield, J.-L. Charlou, J. Knoery, J.-P. Donval, H. Edmond, D. Green, A. Khripounoff, P. Crassous, A. Vangriesheim, J. D. O’Brien, J. Patching, D. Dixon and P. Herring. 2001. A segment scale study of fluxes through the Rainbow hydrothermal plume, $36^{\circ} 14$ N, Mid-Atlantic Ridge. Deep-Sea Res., (submitted).

German, C. R., K. J. Richards, M. D. Rudnicki, M. M. Lam and J. L. Charlou. 1998. Topographic control of a dispersing hydrothermal plume. Earth Planet. Sci. Lett., 156, 267-273.

German, C. R. and R. S. J. Sparks. 1993. Particle recycling in the TAG hydrothermal plume. Earth Planet. Sci. Lett., 116, 129-134.

Herring, P. J. and D. R. Dixon. 1998. Extensive deep-sea dispersal of postlarval shrimp from a hydrothermal vent. Deep-Sea Res., 45, 2105-2118.

Holmes, M. E., P. J. Müller, R. R. Schneider, M. Segl, J. Pätzold and G. Wefer. 1996. Stable nitrogen isotopes in Angola Basin surface sediments. Mar. Geol., 134, 1-12.

Honjo, S. and S. J. Manganini. 1993. Annual biogenic particle fluxes to the interior of the North Atlantic Ocean studied at 34N-21W and 48N-21W. Deep-Sea Res. II, 40, 587-607.

Kaartvedt, S., C. L. Van Dover, L. S. Mullineaux, P. H. Wiebe and S. M. Bollens. 1994. Amphipods on a deep-sea hydrothermal treadmill. Deep-Sea Res., 41, 179-195.

Khripounoff, A. and P. Alberic. 1991. Settling of particles in hydrothermal vent field (East Pacific Rise 13N) measured with sediment traps. Deep-Sea Res., 38, 729-744.

Khripounoff, A., T. Comtet, A. Vangriesheim and P. Crassous. 2000. Near-bottom biological and mineral particle flux in the Lucky Strike hydrothermal vent area (Mid-Atlantic Ridge). J. Mar. Syst., 25, 101-118.

Khripounoff, A., A. Vangriesheim and P. Crassous. 1998. Vertical and temporal variations of particle fluxes in the deep tropical Atlantic. Deep-Sea Res., 45, 193-216.

Kim, S. L. and L. S. Mullineaux. 1998. Distribution and near-bottom transport of larvae and other plankton at hydrothermal vents. Deep-Sea Res. II, 45, 423-440.

Kim, S. L., L. S. Mullineaux and K. R. Helfrich. 1994. Larval dispersal via entrainment into hydrothermal vent plumes. J. Geophys. Res., C99, 12655-12665. 
Klinkhammer, G. P., C. S. Chin, C. Wilson and C. R. German. 1995. Venting from the Mid-Atlantic Ridge at $37^{\circ} 17^{\prime} \mathrm{N}$ : The Lucky Strike hydrothermal site, in Hydrothermal vents and processes, L. M. Parson, C. L. Walker and D. R. Dixon, eds., Geological Society, London, 87-96.

Le Pennec, M., A. Donval and A. Herry. 1990. Nutritional strategies of the hydrothermal ecosystem bivalves. Prog. Oceanogr., 24, 71-80.

Marguillier, S., G. Van Der Velde, F. Dehairs, M. A. Hemminga and R. Rajagopal. 1997. Trophic relationships in an interlinked mangrove-seagrass ecosystem as traced by $\delta^{13} \mathrm{C}$ and $\delta^{15} \mathrm{~N}$. Mar. Ecol. Prog. Ser., 151, 115-121.

McCollom, T. M. 2000. Geochemical constraints on primary productivity in submarine hydrothermal vent plumes. Deep-Sea Res. I, 47, 85-101.

Mullineaux, L. S. and S. C. France. 1995. Dispersal mechanisms of deep-sea hydrothermal vent fauna, in Seafloor Hydrothermal Systems: Physical, Chemical, Biological and Geological Interactions, S. E. Humphris, R. A. Zierenberg, L. S. Mullineaux and R. E. Thomson, eds., American Geophysical Union, Washington, 408-424.

Mullineaux, L. S., P. H. Wiebe and E. T. Baker. 1995. Larvae of benthic invertebrates in hydrothermal vent plumes over Juan de Fuca Ridge. Mar. Biol., 122, 585-596.

Murton, B. J. and L. J. Redbourn. 1997. Segment-scale hydrothermal energy fluxes from the Mid-Atlantic Ridge. EOS Trans. Am. Geophys. Union, 78, 842.

Newton, P. P., R. S. Lampitt, T. D. Jickells, P. King and C. Boutle. 1994. Temporal and spatial variability of biogenic particle fluxes during the JGOFS northeast Atlantic process studies at 47N, 20W. Deep-Sea Res., 41, 1617-1642.

Renninger, G. H., L. Kass, R. A. Gleeson, C. L. Van Dover, B.-A. Batelle, R. N. Jinks, E. D. Herzog and S. C. Chamberlain. 1995. Sulfide as a chemical stimulus for deep-sea hydrothermal vent shrimp. Biol. Bull., 189, 69-76.

Roth, S. E. and J. Dymond. 1989. Transport and settling of organic material in the deep-sea hydrothermal plume: evidence from particle flux measurements. Deep-Sea Res., 36, 1237-1254.

Thurnherr, A. M. and K. J. Richards. 2001. Hydrographic setting of the Rainbow hydrothermal plume (36 $14^{\prime} \mathrm{N}$, Mid-Atlantic Ridge). J. Geophys. Res., (in press).

Vereshchaka, A. L. and G. M. Vinogradov. 1999. Visual observations of the vertical distribution of plankton throughout the water column above Broken Spur vent field, Mid-Atlantic Ridge. Deep-Sea Res. I, 46, 1615-1632.

Walker, S. H. and E. T. Baker. 1988. Particle-size distributions within hydrothermal plumes over the Juan de Fuca ridge. Mar. Geol., 78, 217-226.

Waser, N. A. D., P. J. Harrison, B. Nielsen, S. E. Calvert and D. H. Turpin. 1998. Nitrogen isotope fractionation during the uptake and assimilation of nitrate, nitrite, ammonium, and urea by a marine diatom. Limnol. Oceanogr., 43, 215-224.

Weliky, K., E. Suess, C. Ungere, P. Muller and K. Fischer. 1983. Problems with accurate carbon measurements in marine sediments and water column particulates: a new approach. Limnol. Oceanogr., 28, 1252-1259.

Wilson, C., J.-L. Charlou, E. Ludford, G. Klinkhammer, C. Chin, H. Bougault, C. German, K. Speer and M. Palmer, 1996. Hydrothermal anomalies in the Lucky Strike segment on the Mid-Atlantic Ridge $\left(37^{\circ} 17^{\prime} \mathrm{N}\right)$. Earth Planet. Sci. Lett., 142, 467-477.

Wilson, C., K. Speer, J.-L. Charlou and H. Bougault. 1995. Hydrography above the Mid-Atlantic Ridge (33-40N) and within the Lucky Strike segment. J. Geophys. Res., B, 100, 20555-20564.

Received: 24 April, 2000; revised: 26 April, 2001. 